\title{
Strategi Pengembangan Budidaya Udang Berkelanjutan di Kawasan Pesisir Kota Tegal, Provinsi Jawa Tengah
}

\section{Sustainable Shrimp Cultivation Development Strategy in Coastal Area of Tegal City, Central Java Province}

\author{
Muchtar $^{1 *}$, Moch. Farkan ${ }^{2}$, Mugi Mulyono ${ }^{2}$ \\ ${ }^{1}$ Program Pascasarjana, Sekolah Tinggi Perikanan Jakarta 12520, Indonesia \\ 2 Teknologi AkuakulturSekolah Tinggi Perikanan Jakarta 12520, Indonesia \\ *Email: muchtar14nov@gmail.com
}

Received : 08 April 2020

Accepted : 28 April 2020

Publish : 31 April 2020

\begin{abstract}
Abstrak
Prospek usaha budidaya udang ditambak saat ini masih menjadikan kegiatan usaha yang menguntungkan. Namun demikian peningkatan produksi harus diikuti dengan penerapan teknologi yang berkelanjutan. Pembukaan lahan baru dan pengelolaan lahan yang sudah ada (eksisting) tetap memperhatikan daya dukung lingkungan, social dan ekonomi.Tujuan Penelitian ini adalah untuk menentukan strategi pengembangan budidaya udang berkelanjutan di kawasan pesisir Kota Tegal, Provinsi Jawa Tengah.Penelitian dilaksanakan bulan Juli sampai dengan Oktober 2019. Penelitian ini merupakan penelitian deskriptif dengan metode studi kasus. Analisa data dilakukan secara deskriptif dan analisis SWOT. Berdasarkan analisis matriks SWOT diperoleh peringkat alternatif strategi pengembangan sebagai berikut, peringkat I stategi SO $(3,28)$, peringkat II strategi WO $(2,99)$, peringkat III strategi ST $(0,69)$ dan peringkat IV strtegi WT $(2,40)$. Sedangkan berdasarkan hasil perhitungan faktor internal diperoleh total nilai sebesar 2,86 dan faktor eksternal sebesar 2,69. Nilai ini menunjukan bahwa usaha budidaya udang vaname di Kawasan pesisir Kota Tegal berada dalam posisi akan mengalami pertumbuhan dan stabilitas produksi, dengan memperhatikan kebutuhan pasar dan penerapan aplikasi teknologi budidaya yang ramah lingkungan.
\end{abstract}

Keyword : Budidaya udang, pengembangan, strategi,teknologi

\begin{abstract}
The current prospect of shrimp aquaculture is still making profitable business activities. However, increased production must be followed by the application of sustainable technology. The opening of new land and the management of existing land still takes into account the environmental, social and economic carrying capacity. The purpose of this study was to determine the strategy for developing sustainable shrimp culture in the coastal area of Tegal City, Central Java Province. The study was conducted from July to October 2019. This research is a descriptive study with a case study method Subdistrict Data analysis was done descriptively and SWOT analysis (Strength, weaknes, opportunity, threat). While based on the calculation of internal factors obtained a total value of 2.86 and external factors of 2.69, This value indicates that the vaname shrimp farming business in the coastal area of Tegal City is in a position to experience growth and production stability, taking into account market needs and the application of environmentally friendly cultivation technology applications.
\end{abstract}

Keyword : Shrimp aquaculture, development, strategy, technology 


\section{PENDAHULUAN}

Kawasan pesisir Kota Tegal mempuyai panjang garis pantai sekitar 7,5 km, dengan luasan tambak 488,8 Ha. Komoditas yang dipelaihara adalah budidaya bandeng, udang, kepiting dan rumput laut.Prospek budidaya udang memberikan harapan yang baik bagi para pembudaya udang.Keuntungan yang baik menjadikan pembukaan lahan budidaya udang dan peningkatan produksi yang tidak berwawasan lingkungan.Oleh karena itu diperlukan startegi pengembangan dalam pemanfaatan lahan tambak untuk budidaya udang. Pemanfaatan potensi lahan, serta penggunaan ilmu dan teknologi budidaya dalam pengembangan perikanan (Hutabarat, 2001). Pembangunan yang tidak berkelanjutan akan menguntungkan sesaat dan kerugian yang dapat mengakibatkan ditutupnya usaha tersebut,

Permasalahan utama dalam pengembangan budidaya udang di Kawasan pesisir Kota Tegal saat ini adalah produksi udang yang tidak stabil. Penurunan kualitas lingkunganyang disebabkan oleh pengelolaan limbah budidaya yang belum maksimal diterapkan, pencemaran lingkungan darilimbah perumahan, pariwisata serta pengembangan pembangunan pelabuhan. Oleh karena itu pengembangan budidaya udang harus dilakukan secara terintergasi berbagai kepentingan yang memanfaatkan lahan pesisir Kota Tegal. Berbagai kendala dalam pengembangannya antara lainadalah permodalan. Budidaya udang membutuhkan biaya besar yakni inventasi dan biaya operasioal yang cukup tinggi, peraturan dan perundangan, sarana dan prasarana, SDM, sosial budaya, teknologi dan lainnya. Berkenaan dengan hal tersebut untuk mengoptimalkan produksi agar berkelanjutanstrategi pengembangannya. Untuk itu potensi yang ada perlu dikembangkan sesuai dengan daya dukung lingkungan yang dimiliki serta memperhatikan tata ruang yang ada (Sagita A, et al. 2015). Tujuan penelitian adalah untuk menentukanstrategi pengembangan budidaya udang berkelanjutan di kawasan pesisir Kota Tegal. Penelitian dilaksanakan 
bulan Juli sampai dengan Oktober 2019 di tambak kawasan pesisir Kota Tegal.

\section{METODE PENELITIAN}

\section{Waktu dan Tempat Penelitian}

Penelitian

dilaksanakan

daribulan Juli 2019 sampai

dengan bulan Oktober 2019.

Tempat penelitian di tambak udang vaname Kota Tegal yang meliputi wilayah Kecamatan

Tegal Timur, Kecamatan Tegal

Barat dan Kecamatan

Margadana.

\section{Analisa Data}

Analisa data dilakukan
secara deskriptif dan analisis
SWOT (Strenght, weaknes,
opportunity, threat). Jenis data
yang dikumpulkan berupa data
primer dan data sekunder. Data
primer meliputi data terkait
dengan kegiatan budidaya udang
di lapangan secara langsung dari

responden dengan metode sensus, untuk mendukung analisis SWOT menggunakan responden melalui koesioner. Data penelitian yang terkumpul setelah diolah kemudian dianalisis dengan menggunakan analisis deskriptif dan analisis SWOT. Kegiatan ini dilakukan untuk melihat tingkat kekuatan, kelemahan, peluang dan ancaman yang dihadapi dalam budidaya udang.Selanjutnya diprediksi kemungkinan pengembangan usaha budidaya udang di Kawasan Pesisir Kota Tegal.

\section{HASIL DAN PEMBAHASAN}

Kawasan pesisir kota Tegal merupakan kota pantai (berbatasan dengan laut) dengan panjang garis pantai sekitar 7,5 km, memiliki potensi perikanan yang cukup besar, khususnya perikanan laut. Hal ini didukung oleh adanya tiga tempat

Tabel 1. Luas penggunaan lahan bukan sawah menurut kecamatandi Kota Tegal (hektar).

\begin{tabular}{ccccccc}
\hline No & Kecamatan & $\begin{array}{c}\text { Bangunan/ } \\
\text { Pekarangan }\end{array}$ & $\begin{array}{c}\text { Tegal/ } \\
\text { Kebun }\end{array}$ & Tambak & $\begin{array}{c}\text { Lain- } \\
\text { Lain }\end{array}$ & $\begin{array}{c}\text { Jumlah } \\
\text { Tanah } \\
\text { Kering }\end{array}$ \\
\hline 1 & Tegal Selatan & 535,50 & 0,50 & - & - & 536 \\
2 & Tegal Timur & 545,04 & 29,20 & 42,4 & - & 617 \\
3 & Tegal Barat & 1039,18 & 7,42 & 417,4 & - & 1464 \\
4 & Margadana & 599,00 & 5,00 & 29,0 & 12,0 & 645 \\
\hline & Jumlah & 2719,08 & 42,12 & 488,8 & 12,0 & 3262 \\
\hline
\end{tabular}

Sumber : BPS Kota Tegal 2019. 
pelelangan ikan (TPI Tegalsari, Muarareja dan Pelabuhan). Sementara potensi perikanan budidaya (tambak), dengan luasan tambak 488,8 Ha, umumnya digunakan untuk budidaya bandeng, udang, nila, lele dan rumput laut. Tabel 1. Luas penggunaan lahan bukan sawah menurut kecamatandi Kota Tegal (hektar).

Lahan tambak yang ada sejumlah 488,8 Ha, masih sangat potensial untuk dikembangkan sebagai usaha kegiatan budidaya udang vaname. Saat ini baru digunakan sebagai lahan budidaya udang vaname baru 67,5 Ha atau baru $13,8 \%$ dari lahan tambak yang ada. Sebagian besarlahan tersebut baru digunakan secara tradiosional dalam pemanfaatanya yaitu untuk usaha budidaya seperti bandeng, udang, nila, lele dan rumput laut. Perkembangan produksi perikanan budidaya tambak di KotaTegal tersaji pada tabel 2 dan gambar 1 .

Dari data menunjukan perkembangan perikanan budidaya di Kota Tegal yang berbeda dari tahun 2012 sampai tahun 2018. Fluktuasi perkembangan dari tabel tersebut akan lebih jelas terlihat pada gambar 1. Data yang ada menunjukan fluktuasi usaha budidaya tambak mulai tahun 2012/2013 dari jumlah produksi kurang lebih $654000 \mathrm{~kg}$, mengalami kenaikan pada tahun 2014 menjadi 712500 kg, kemudian turun produksinya menjadi 500710 kg pada tahun 2015, dan naik lagi produksinya menjadi $811020 \mathrm{~kg}$, kemudian berturut-turut mengalami penurunan produksi menjadi 768670 $\mathrm{kg}$ ditahun 2017, turun kembali produksinya pada tahun 2018 menjadi $597 \quad 337$ kg. Fluktuasi produksi terjadi dimungkinkan karena belum adanya strategi

Tabel 2. Produksi perikanan budidaya di Kota Tegal.

\begin{tabular}{cccccc}
\hline No & Tahun & Tambak $(\mathrm{kg})$ & Perk. Umum $(\mathrm{kg})$ & Kolam $(\mathrm{kg})$ & Benih (ekor) \\
\hline 1 & 2012 & 658150 & 31690 & 356500 & 4202000 \\
2 & 2013 & 650490 & 31800 & 688200 & 1325000 \\
3 & 2014 & 712500 & - & - & - \\
4 & 2015 & 500710 & - & 206900 & - \\
5 & 2016 & 811020 & - & 320700 & 459000 \\
6 & 2017 & 769670 & - & 432700 & 4602000 \\
7 & 2018 & 597337 & 20200 & 551800 & 1380000 \\
\hline
\end{tabular}

Sumber : BPS Kota Tegal 2019. 
Tabel 3. Produksi perikanan budidaya di Kota Tegal.

\begin{tabular}{|c|c|c|c|c|c|}
\hline No & Tahun & Tambak (Rp) & Perk Umum (Rp) & Kolam (Rp) & $\overline{\mathrm{E}}$ \\
\hline 1 & 2012 & 8.245 .436 .000 & 21740000 & 445780000 & 8 \\
\hline 2 & 2013 & 8.335 .338 .000 & 21805000 & 652118000 & $2:$ \\
\hline 3 & 2014 & 8.640 .648 .000 & - & - & \\
\hline 4 & 2015 & 7.622 .523 .000 & - & 641850000 & \\
\hline 5 & 2016 & 12.897 .678 .000 & - & 523112000 & $7:$ \\
\hline 6 & 2017 & 9.849 .522 .300 & - & 566580000 & $6 t$ \\
\hline 7 & 2018 & 8.617 .823 .000 & 40400000 & 325899000 & $4]$ \\
\hline
\end{tabular}

Sumber : BPS Kota Tegal 2019.

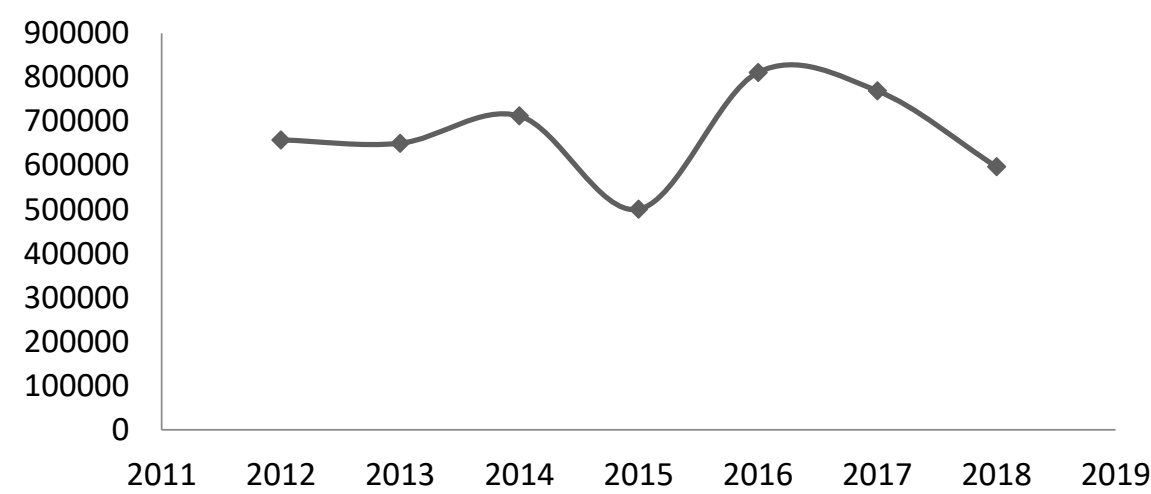

Gambar 1. Produksi perikanan budidaya (tambak) di Kota Tegal

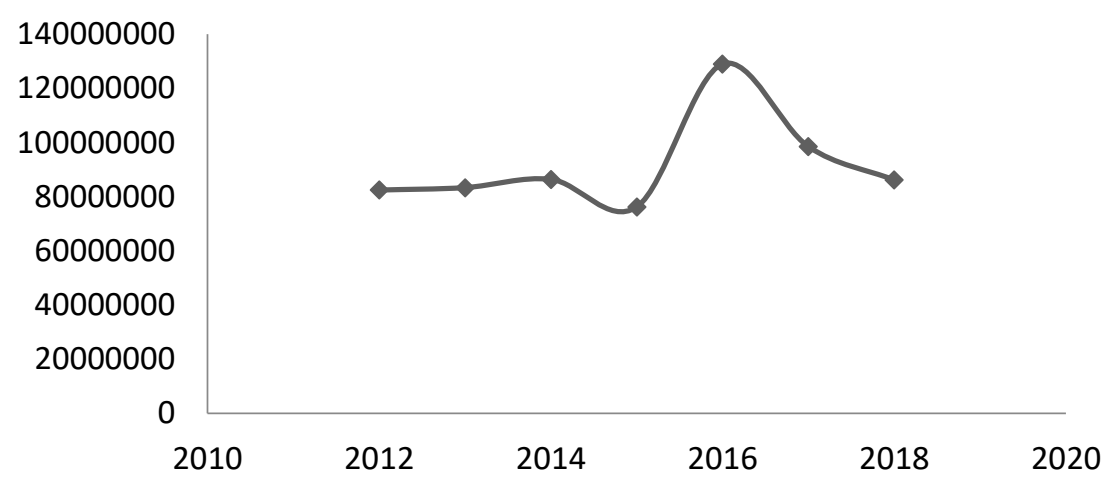

Gambar 2. Nilai produksi perikanan budidayadi Kota Tegal.

budidaya yang baik, serta kurang berpengaruh juga terhadap nilai memperhatikan daya dukung produksi budidaya,dapat dilihat tabel lingkungan. Kegiatan budidaya yang 3 dan gambar 2. Secara umum dari tidak memperhatikan daya dukung tabel yang ada menunjukan adanya dan keberlanjutan dapat jumlah nilai produksi yang berbeda menyebabkan kegagalan (Ahmad, dari setiap produksi yang dihasilkan 2006). baik tambak, kolam maupun benih.

Seperti kegagalan budidaya Perkembangan nilai produksi udang windu pada tahun1990an. sesuai dengan jumlah produksi setiap Hasil produksi yang berbeda, tahunya.Dari data jumlah produksi 
dan nilai produksi menunjukan adanya fluktusi, baik jumlah produksi maupun nilai produksi berbeda setiap tauhnya, mengalami penurunan nilai produksi padatahun 2015, kemudian naik kembali pada tahun 2016, kemudian turun lagi pada tahun 2017 sampai tauhn 2018. Penurunan nilai produksi disebabkan juga karena jumlah produksinya mengalami penurunan. Meskipun pemnafaatan lahan tambak untuk budidaya udang relatif kecil $13.8 \%$, namun dari data menunjukan bahwa produksi budidaya secara umum yang dihasilkan tidak stabil. Hal ini berpengaruh pula terhadap pendapatan dan nilai dari jumlah produksinya. Penurunan produksi berpengaruh terhadap pendapatan pembudidaya. Penurunan produksi disebabkan oleh tercemarnya lingkungan. Baik dari cemaran yang berasal dari penduduk, pariwisata, pelabuhan juga karena faktor pengelolaan limbah udang vaname yang kurang memadai. Pencemaran tersebut mengakibatkan kesehatan kultivan yang menjadi kurang baik, hingga menyebakan penyakit dan kematian. Bahwa penyakit dapat menyebabkan kematian organisme budidaya (Sukenda, dkk. 2011). Data produksi perkomoditas perikanan

Tabel 4. Produksi perikanan budidaya di Kota Tegal.

\begin{tabular}{|c|c|c|c|c|c|c|c|c|c|c|c|}
\hline \multirow{3}{*}{ No } & \multirow{3}{*}{$\begin{array}{c}\text { Jenis } \\
\text { Budidaya }\end{array}$} & \multicolumn{10}{|c|}{ Produksi (dalam ton) } \\
\hline & & \multicolumn{2}{|c|}{ Triwulan 1} & \multicolumn{2}{|c|}{ Triwulan 2} & \multicolumn{2}{|c|}{ Triwulan 3} & \multicolumn{2}{|c|}{ Triwulan 4} & \multicolumn{2}{|c|}{ Total } \\
\hline & & 2017 & 2018 & 2017 & 2018 & 2017 & 2018 & 2017 & 2018 & 2017 & 2018 \\
\hline 1 & Nila & 6,35 & 13,25 & 5,35 & 13,25 & 5,5 & 13,25 & 2,6 & 0 & 19,8 & 39,75 \\
\hline 2 & Gurame & - & 13,25 & - & 13,25 & - & 13,25 & - & 0 & 0 & 39,75 \\
\hline 3 & Lele & 15,18 & 3,975 & 10,58 & 7,28 & 12,21 & 14,575 & 5,3 & 29,35 & 43,27 & 55,18 \\
\hline 4 & Bandeng & 140,62 & 22,205 & 150,75 & 33,307 & 144,5 & 53,385 & 152,58 & 106,35 & 588,45 & 215,247 \\
\hline 5 & U.Vaname & 10 & 77,762 & 15,56 & 98,988 & 12,07 & 24 & 13,52 & 26,46 & 51,25 & 227,21 \\
\hline \multirow[t]{2}{*}{6} & R. laut & 28,8 & 5 & 29,5 & 6 & 8,6 & 0 & 0 & 9,2 & 66,9 & 20,2 \\
\hline & & 201,05 & 135,442 & 211,74 & 172,075 & 182,88 & 118,46 & 174 & 171,36 & 769,67 & 597,337 \\
\hline
\end{tabular}

Sumber : Dinas Kelautan dan Perikanan Kota Tegal (2019).

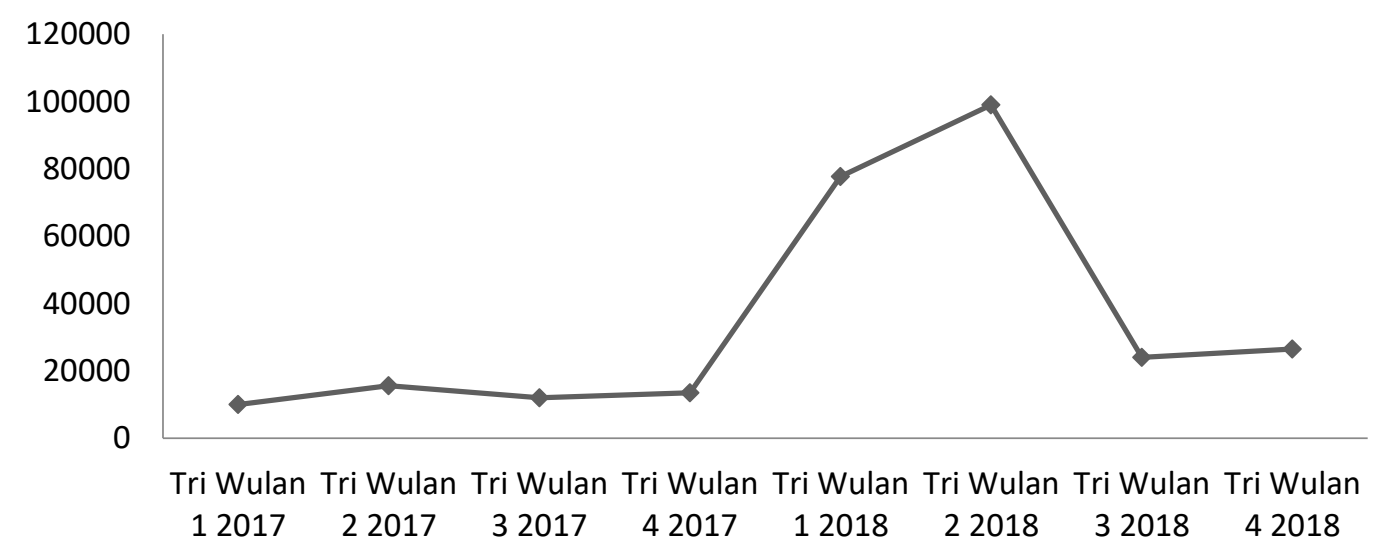

Gambar 3. Produksi udang vaname. (Sumber : Dinas Kelautan dan Perikanan Kota Tegal (2019)) 
budidaya dua tahun dari tahun 2017 sampai tahun 2018 di Kota Tegal dapat dilihat ada tabel 4 .

Produksi perikanan budidaya di Kota Tegal meliputi nila, gurame, lele, bandeng, rumput laut dan udang vaname. Masing-masing komoditas jumlah produksi berfariasi dari triwulan pertama ditahun 2017 hingga triwulan ke emapt pada tahun 2018. Khusus perkembangan produksi udang vaname dapat dilihat pada gambar 3 .

\section{Kondisi Budidaya Udang Vaname di Kota Tegal}

Kegiatan budidaya udang vaname di wilayah pesisir Kota Tegal baru dimulai sekitar tahun 2013/2014, sejak penurunan produksi hinggakegagalan budidaya udang windu tahun 1990an.Mayarakat melakukan usaha budidaya secara tradisional,seperti budidaya bandeng, rumput laut dan udang. Hal ini dilakukan sebagai efisiensi biaya juga berpotensi dalam pemulihan lahan budidaya.Perbaikan lingkungan dengan penanaman hutan bakau (mangrove) serta perbaikan saluran tambak. Budidaya secara tradisional dengan memperhatikan kelestarian lingkungan, hingga berkembang saat ini dengan menggunakan teknologi budidaya yang ramah lingkungan. Budidaya udang di wilayah pesisir Kota Tegal meliputi tiga wilayah kecamatan diantaranya Kecamatan Margadana di Kelurahan Margadana, Kecamatan Tegal Barat di Kelurahan Muarareja dan Kecamatan Tegal Timur di Kelurahan Panggung. Jumlah pembudidaya udang vaname terdapat 16 orang/kelompok pembudidaya dengan kisaran luas tambak 67500 $\mathrm{m}^{2}$, tersaji pada Tabel 5. Sedangkan Produksi udang yang dihasilkan tiap tri wulan masih berbeda jumlahnya atau fluktuatif meskipun cenderung mengalami kenaikan produksi seperti gambar 3 .

Keberhasilan usaha budidaya udang vaname pada siklus sebelumnya membuat pembudidaya bersemangat untuk meningkatkan produksi. Dengan cara meningkatkan

Tabel 5. Data lahan budidaya udang vaname di Kota Tegal.

\begin{tabular}{cccc}
\hline No & Kecamatan & Luas $^{2}$ & Jumlah Pembudidaya \\
\hline 1 & Kecamatan Margadana & 7000 & 2 \\
2 & Kecamatan Tegal Barat & 25500 & 5 \\
3 & Kecamatan Tegal Timur & 35000 & 9 \\
& Jumlah & 67500 & 16 \\
\hline
\end{tabular}

Sumber : Hasil penelitian. 
kepadatan hingga mencapai 350 ekor $/ \mathrm{m}^{2}$, diharapkan dapat meningkatkan pruduksi saat panen. Jumlah produksi tertinggi terdapat pada tri wulan ke 2 di tahun 2018.Dari data menunjukan bahwa terjadi kenaikan produksi udang yang cukup tinggi di akhir triwulan 4 pada tahun 2017 sampai triwulan kedua ditahun 2018. Kenaikan produksi tersebut desebabkan oleh target produksi yang tinggi dengan harapan mendaptkan keuntungan atau pendapatan yang besar. Peningkatan produksi dilakukan dengan cara penambahan kepadatan tebar udang.

Pada awalnya kepadatan ratarata 100 ekor $/ \mathrm{m}^{2}$, dinaikan menjadi lebih dari $350 \mathrm{ekor} / \mathrm{m}^{2}$. Peningkatan produksipun naik cukup tinggi.Peningkatan produksi dengan cara menambah kepadatan tebar udang tinggi, sayangnya tidak diimbangi dengan pengelolaan limbah yang memadai. Akibatnya masalah kualitas air dan lingkungan jadi tercemar. Penyakit mulai menyerang, pertumbuhan udang tidak optimal. Dan pada akhirnya produksi yang diharapkan terus meningkat menjadi tidak tercapai.
Produksipun langsung turun dratis pada triwulan ketiga ditahun 2018. Salah satu faktor serangan penyakit yang menyebabkan kematian udang adalah penebaran benih yang melebihi kapasitas daya dukung lingkungan (Sumiarsih, 2018)Keterbatasan pengelolaan limbah, pencemaran lingkungan dan keterbatasan daya dukung lahan, menyebabkan produksi udang yang tinggi tidak bisa bertahan lama. Hal ini sesuai dengan (Hermanto, 2007) bahwa kerusakan lingkungan akibat pembuangan limbah berefek kepada organisme budidaya. Dampak dari itu terjadi penurunan produksi. Pada tri wulan ke tiga produksi udang langsung turun kembali. Kuatir gagal panen lagi, siklus berikutnya pembudidaya tidak berani tebar benih dengan kepadatan yang sangat tinggi. Berdasarkan penurunan produksi, serta kegagalan panen udang windu pada tahun 1990an, menjadikan pembudidaya kembali untuk lebih berhati-hati dalam melakukan kegiatan budidaya.

Kemampuan pengelolaan limbah yang terbatas, pencemaran lingkungan serta daya dukung lingkungan yang menurun membuat 
pembudidaya tidak berani menebar benih dengan kepadatan yang melebihi dari 100 ekor $/ \mathrm{m}^{2}$. Selanjutnya kegiatan budidaya dilakukan dengan cara yang lebih ramah lingkungan agar usaha budidaya dapat dilakukan secara berkelanjutan.Sesuai dengan (Darmawan, $d k k$, 2004) bahwa pengelolaan budidaya harus sesuai dengan teknik, prosedur dengan menerapkan sistem tertutup dan berwawasan lingkungan.

$\begin{array}{lrr}c & \text { demikian } \\ \text { permasalahan yang } & \text { kompleks } \\ \text { dalam pengelolaan } & \text { kawasan } \\ \text { budidaya udang di } & \text { tambak, } \\ \text { memerlukan sinergitas } & \text { antar } \\ \text { factor seperti daya } & \text { dukung, } \\ \text { kelembagaan, } & \text { ekonomi, } \\ \text { lingkungan, social. Keterpaduan } \\ \text { anatar sector ini akandianalisis } \\ \text { dengan menggunakan } & \text { SWOT } \\ \text { sehingga diperoleh } & \text { kegiatan } \\ \text { prioritas dalam } & \text { menetapkan } \\ \text { strategi pembangunan } & \text { kawasan } \\ \text { udang berkelanjutan. } & \end{array}$

\section{Analisis Pengembangan Budidaya}

Udang Berkelanjutan dengan SWOT

Proses pengambilan keputusan strategis selalu berkaitan dengan latar belakang, potensi dan permasalahan yang ada baik secara internal berupa kekuatan dan kelemahan maupun secara eksternal berupa peluang dan ancaman. Strategi dan pengembangan budidaya udang di Kawasam pesisir Kota Tegal dilakukan dengan menganalisis faktor-faktor strategis usaha budidaya melalui analisis SWOT yaitu menganalisis kekuatan (Strenghts), kelemahan (Weaknesses), peluang (Opportunity) dan ancaman (Threats).

1. Analisis Faktor Internal

Analisis faktor internal berhubungan dengan kekuatan dan kelemahan dari strtegi pengembangan budidaya udang di Kota Tegal. Setelah ditentukan beberapa faktor internal, selanjutnya disusun matrik strategi internal. Hasil perhitungan dari matrik faktor strategi internal (IFAS-Internal Strategic Factors Analysis Summary) dapat dilihat pada Tabel 6.

Berdasarkan hasil analisis SWOT pada matrik faktor strategi internal kekuatan (S) yang paling berpengaruh terhadap pengembangan 
Tabel 6. .Matrik faktor strategi internal (IFAS-Internal Strategic Factors Analysis Summary).

\begin{tabular}{|c|c|c|c|c|c|}
\hline & $\begin{array}{c}\text { FAKTOR-FAKTOR } \\
\text { STRATEGI INTERNAL }\end{array}$ & BOBOT & RATING & SKOR & KOMENTAR \\
\hline \multicolumn{6}{|c|}{ KEKUATAN (STRENGHTS) } \\
\hline 1 & Ketersediaan Teknologi & 0,15 & 4 & 0,60 & $\begin{array}{l}\text { Teknologi budidaya secara } \\
\text { intensif }\end{array}$ \\
\hline 2 & Ketersediaan lahan & 0,04 & 3 & 0,12 & $\begin{array}{c}\text { Lahan budidaya tersedia } \\
488,8 \mathrm{Ha}\end{array}$ \\
\hline 3 & $\begin{array}{l}\text { Peralatan dan sarana } \\
\text { danprasarana produksi } \\
\text { tersedia }\end{array}$ & 0,09 & 3 & 0,27 & $\begin{array}{c}\text { Sarana dan prasarana } \\
\text { produksi sangat tersedia }\end{array}$ \\
\hline 4 & Kebijakan pemerintah & 0,10 & 4 & 0,40 & Dukungan pemerintah besar \\
\hline 5 & Manajemen budidaya & 0,09 & 2 & 0,12 & $\begin{array}{l}\text { Peningkatan kemampuan } \\
\text { manajemenbudidaya }\end{array}$ \\
\hline \multicolumn{6}{|c|}{$\begin{array}{l}\text { KELEMAHAN } \\
\text { (WEAKNESSES) }\end{array}$} \\
\hline 1 & Modal & 0,09 & 3 & 0,32 & Perlu modal dari pihak lain \\
\hline 2 & Kontruksi lahan budidaya & 0,12 & 2 & 0,24 & $\begin{array}{c}\text { Dibuat konstruksi tambak } \\
\text { baru }\end{array}$ \\
\hline 3 & Saluran inlet dan outlet & 0,05 & 2 & 0,10 & $\begin{array}{c}\text { Penataan saluran secara } \\
\text { terpisah }\end{array}$ \\
\hline 4 & Sumberdaya manusia & 0,09 & 3 & 0,21 & $\begin{array}{l}\text { Perlu pelatihan teknis } \\
\text { budidaya }\end{array}$ \\
\hline 5 & Tarif PLN & 0,06 & 2 & 0,12 & $\begin{array}{l}\text { Tarif dasar listrik perlu } \\
\text { subsidi dari pemerintah }\end{array}$ \\
\hline 6 & $\begin{array}{l}\text { Pengolahan limbah tidak } \\
\text { ada }\end{array}$ & 0,12 & 3 & 0,36 & $\begin{array}{l}\text { Pembuatan ipal dari buangan } \\
\text { limbah }\end{array}$ \\
\hline & Jumlah & 1.00 & & 2,86 & \\
\hline
\end{tabular}

Sumber : Hasil penelitian.

budidaya udang di Kota Tegal adalah ketersediaan teknologi $(0,60)$, kelemahan (W) terbesar saluran inlet dan outlet $(0,10)$.

\section{Analisis Faktor Eksternal}

Analisis faktor eksternal berhubungan dengan peluang dan ancaman dari strategi pengembangan budidaya udang di Kota Tegal. Setelah ditentukan beberapa faktor eksternal, selanjutnya disusun matrik strategi eksternal. Hasil perhitungan dari matrik faktor strategi eksternal (EFAS- External Strategic Factors
Analysis Summary) dapat dilihat pada Tabel 7.

Berdasarkan hasil analisis SWOT pada matrik faktor strategi eksternal peluang $(\mathrm{O})$ paling besar dalam pengembangan budidaya udang di Kota Tegal adalah kebutuhan pasar udang yang masih besar $(0,80)$ sedangkan ancaman $(\mathrm{T})$ terbesar adalah abrasi $(0,10)$.

3. Stategi Pengembangan Budidaya

Udang Berkelanjutan di Kota Tegal

Dalam menentukan strategi budidaya udang berkelanjutan di 
Tabel 7. Matrik faktor strategi eksternal.

\begin{tabular}{|c|c|c|c|c|}
\hline $\begin{array}{c}\text { FAKTOR-FAKTOR } \\
\text { STRATEGI EKSTERNAL }\end{array}$ & BOBOT & RATING & SKOR & KOMENTAR \\
\hline \multicolumn{5}{|l|}{ PELUANG (OPPORTUNITY) } \\
\hline 1 Kebutuhan pasar yang besar & 0,20 & 4 & 0,80 & $\begin{array}{l}\text { Udang vaname masih } \\
\text { menjadi primadona pasar } \\
\text { dunia }\end{array}$ \\
\hline $\begin{array}{l}2 \text { Harga udang yang stabil dan } \\
\text { kompetitif }\end{array}$ & 0,05 & 3 & 0,15 & Harga udang lebih stabil \\
\hline 3 Wisata kuliner /edukatif & 0,06 & 2 & 0,12 & $\begin{array}{c}\text { Produksi udang telah } \\
\text { dikenal masyarakat } \\
\text { sebagai produk unggulan } \\
\text { daerah }\end{array}$ \\
\hline 4 Lahan tambak luas & 0,09 & 3 & 0,27 & $\begin{array}{l}\text { Luas lahan budidaya } \\
\text { masih sangat potensial }\end{array}$ \\
\hline 5 Aplikasi teknologi & 0,10 & 3 & 0,30 & $\begin{array}{c}\text { Peningkatan teknologi } \\
\text { budidaya melalui } \\
\text { aplikasinya }\end{array}$ \\
\hline \multicolumn{5}{|l|}{ ANCAMAN (THREATS) } \\
\hline 1 Pencemaran lingkungan & 0,20 & 3 & 0,60 & $\begin{array}{l}\text { Dilakukannya usaha } \\
\text { budidaya udang sistem } \\
\text { resirkulasi tertutup }\end{array}$ \\
\hline 2 Serangan penyakit & 0,10 & 2 & 0,20 & Penurunan kualitas air \\
\hline 3 Ketidak sesuaian tata ruang & 0,15 & 1 & 0,15 & $\begin{array}{c}\text { Kebijakan pemerintah } \\
\text { dalam perencanaan } \\
\text { RTRW Kota Tegal }\end{array}$ \\
\hline 4 Abrasi & 0,05 & 2 & 0,10 & $\begin{array}{c}\text { Kondisi alam yang terjadi } \\
\text { dengan cuaca yang tidak } \\
\text { mendukumg }\end{array}$ \\
\hline Jumlah & 1,00 & & 2,69 & \\
\hline
\end{tabular}

Sumber : Hasil penelitian.

kawasan pesisir Kota Tegal, setelah menyusun matrik IFAS dan EFAS, sealnjutnya dirumuskan alternatif strategi berdasarkan matrik SWOT seperti pada tabel 8 .

Selanjutnya jumlah total skor dari variabel-variabel internal (kekuatan dan kelemahan) serta jumlah total skor pembobotan/nilai tertimbang dari peluang dan dan ancaman dapat dilihat pada tabel 9.

Jumlah total skor pembobotan dari variabel-variabel internal (kekuatan : 1,51 dan kelemahan : $1,35)$, yaitu sebesar 2,86 , serta total skor pembobotan dari variabelvariabel eksternal (peluang : 1,64 dan ancaman : 1,05), sebesar 2,69. Berikutnya dimasukan kedalam perhitungan skor pada Matrik IFAS dan EFAS yang tersaji pada gambar 4.

Berdasarkan matrik faktor strategi internal (IFAS) dan eksternal (EFAS) pengembangan usaha budidaya udang di Kota Tegal yang 
Tabel 8. Matrik kekuatan-kelemahan dan peluang-ancaman (SWOT)..

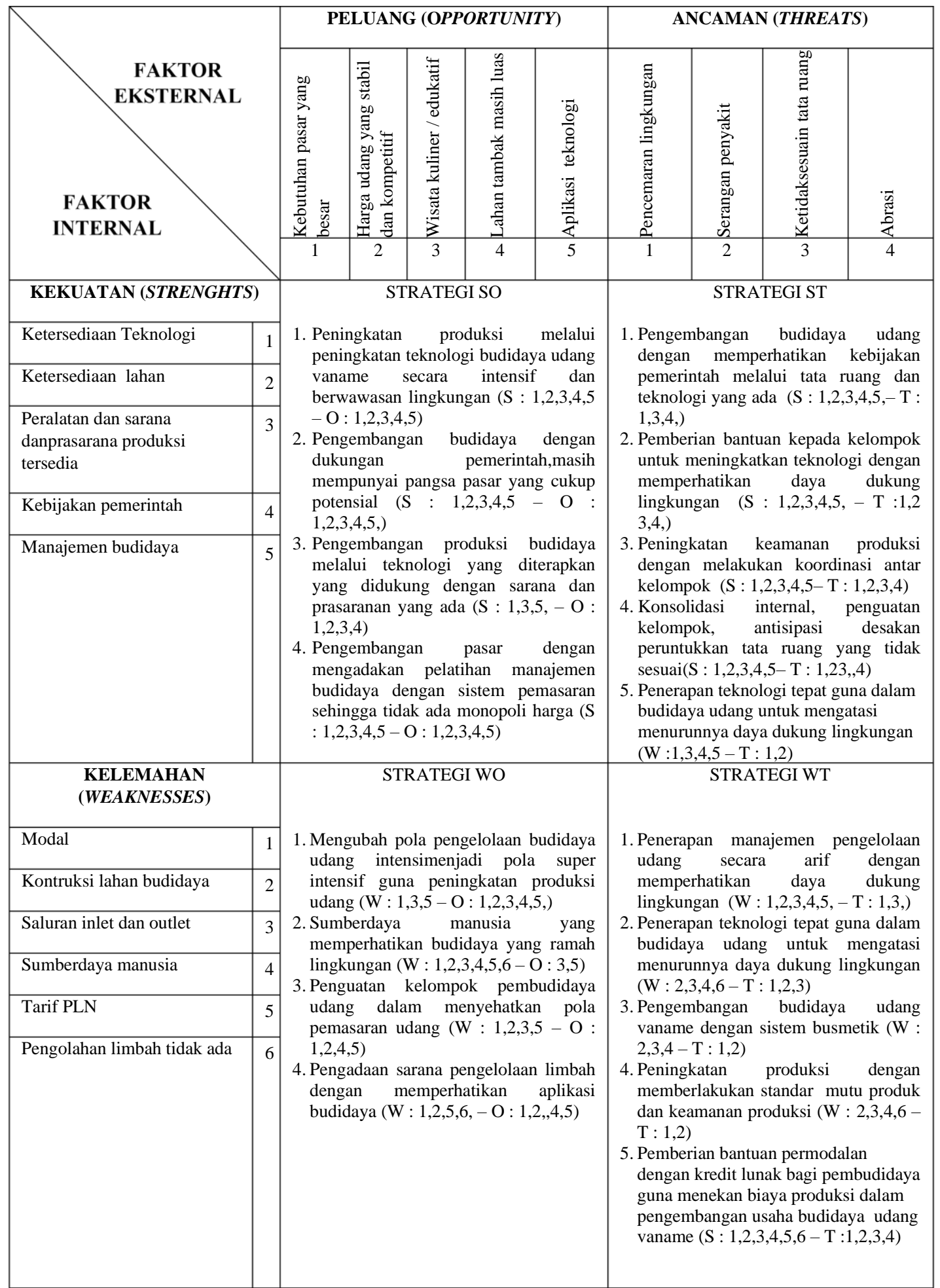

Sumber : Hasil penelitian.

tersaji pada Tabel 5 dan 6 , diperoleh

bahwa nilai total faktor strategi

internal (IFAS) sebesar 2,86 dan eksternal (EFAS) sebesar 2,69; sehingga jika dimasukkan dalam matrik internal eksternal usaha 
Tabel 9. Daftar nilai terboboti tiap unsur SWOT.

\begin{tabular}{|c|c|c|c|c|c|c|c|}
\hline Kekuatan & \multirow{2}{*}{$\begin{array}{c}\text { Nilai } \\
\text { Terbobot }\end{array}$} & Kelemahan & \multirow{2}{*}{$\begin{array}{c}\text { Nilai } \\
\text { Terbobot }\end{array}$} & \multirow{2}{*}{$\begin{array}{l}\text { Peluang } \\
\text { Opport } \\
\text { unities }\end{array}$} & \multirow{2}{*}{$\begin{array}{c}\text { Nilai } \\
\text { Terbobot }\end{array}$} & \multirow{2}{*}{$\frac{\text { Ancaman }}{\text { Threats }}$} & \multirow{2}{*}{$\begin{array}{c}\text { Nilai } \\
\text { Terbobot }\end{array}$} \\
\hline Strenghts & & Weaknesses & & & & & \\
\hline S1 & 0,60 & W1 & 0,32 & O1 & 0,80 & $\mathrm{~T} 1$ & 0,60 \\
\hline S2 & 0,12 & W2 & 0,24 & $\mathrm{O} 2$ & 0,15 & $\mathrm{~T} 2$ & 0,20 \\
\hline S3 & 0,27 & W3 & 0,10 & $\mathrm{O} 3$ & 0,12 & $\mathrm{~T} 3$ & 0,15 \\
\hline S4 & 0,40 & W4 & 0,21 & $\mathrm{O} 4$ & 0,27 & $\mathrm{~T} 4$ & 0,10 \\
\hline \multirow[t]{2}{*}{ S5 } & 0,12 & W5 & 0,12 & O5 & 0,30 & & \\
\hline & & W6 & 0,36 & & & & \\
\hline Jumlah & 1,51 & & 1,35 & & 1,64 & & 1,05 \\
\hline
\end{tabular}

Sumber : Hasil penelitian.

NILAI TOTAL FAKTOR STRATEGI INTERNAL

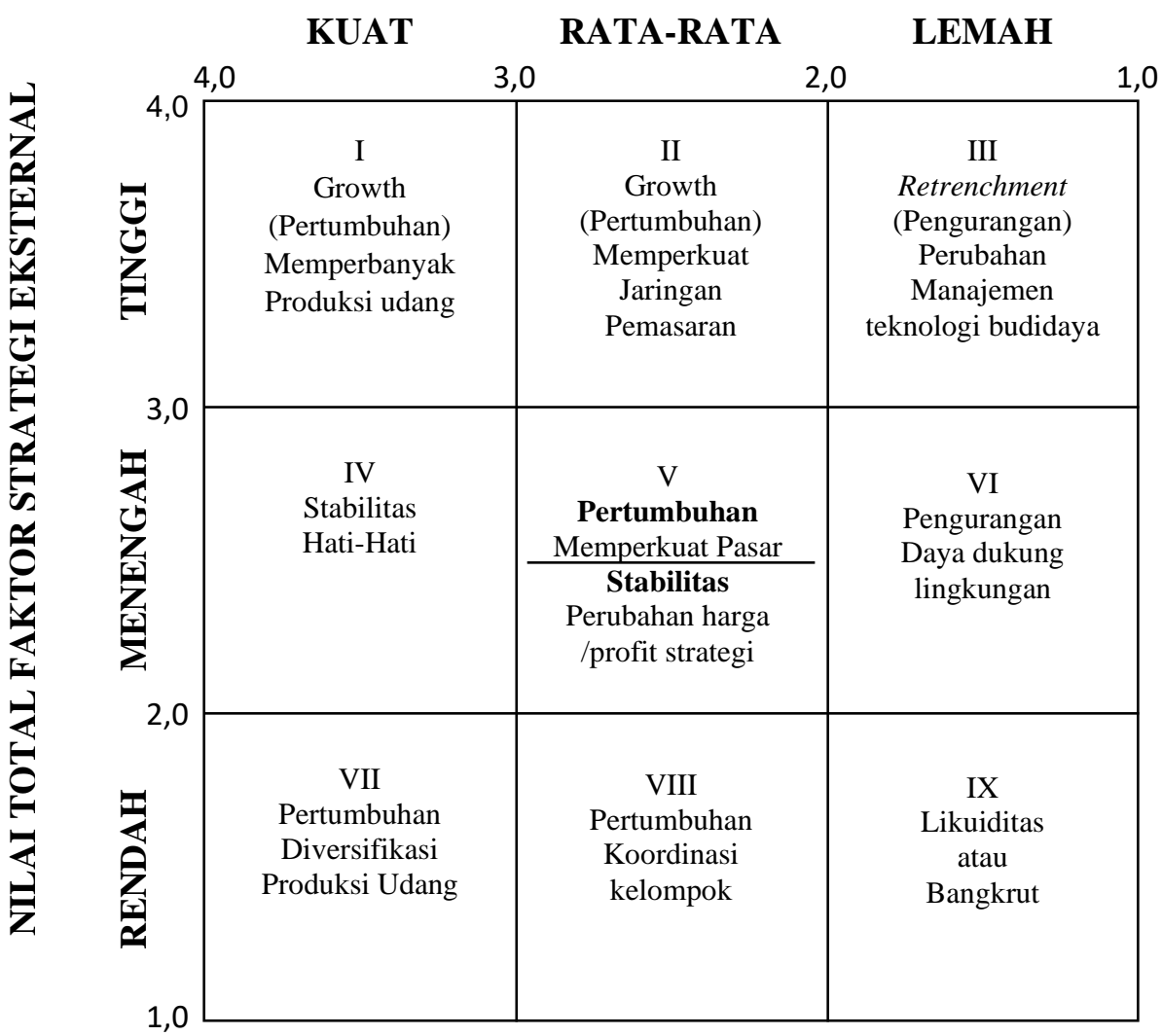

Gambar 4. Ilustrasi matrik internal-eksternal (Sumber: Data primer).

budidaya udang berada dalam posisi sel (segmen) V yang berarti bahwa usaha budidaya udang di Kota Tegal berada pada kondisi yang relatif stabil dan kemungkinan dapat terjadi pertumbuhan.
Berdasarkan nilai-nilai yang sudah terboboti dari faktor internal dan eksternal analisis SWOT pengembangan usaha budidaya udang di Kota Tegal maka diperoleh hasil perhitungan peringkat alternatif 
strategi pengembangan sebagai berikut;

1. Peringkat ke 1:Strategi SO dengan jumlah nilai terbobot 3,28

2. Peringkat ke 2: Strategi WO dengan jumlah nilai terbobot 2,99

3. Peringkat ke 3: Strategi ST dengan jumlah nilai terbobot 2,69

4. Peringkat ke 4: Strategi WT dengan jumlah nilai terbobot 2,40 Sementara berdasarkan hasil perhitungan nilai pada matrik IFAS diperoleh nilai total faktor internal sebesar 2,86 dan EFAS diperoleh nilai total faktor eksternal sebesar 2,69.Berdasarkan perhitungan skor pada Matrik IFAS dan EFAS internal dan eksternal usaha budidaya udang vaname berada dalam posisi sel (segmen) V.Pada fase ini usaha akan mengalami pertumbuhan dan stabilitas produksi.Pada segmen $\mathrm{V}$ dalam matrik internal eksternal usaha budidaya udang vaname pada skor nilai 2,86 dan 2,69.Posisi yang cenderung lebih dekat pada segmen stabilitas. Secara umum strategi pengembangan yang perlu dilakukan adalah pengembangan budidaya udang vaname.Kegiatan budidaya dapat dilakukan dengan strategi musim tanam yaitu menghindari musim peralihan serta penerapan aplikasi teknologi budidaya udang yang ramah lingkungan.

\section{Langkah Pengembangan Budidaya} udang di Kawasan Pesisir Kota Tegal

Langkah-langkah pemecahan permasalahan dalam menghadapi kegagalan budidaya udang di Kota Tegal, meliputi :

1. Pengembangan budidaya udang dengan memperhatikan kebijakan pemerintah melalui tata ruang dan teknologi yang ada.

2.Perlu penerapan teknologi tepat guna dalam budidaya udang untuk mengatasi menurunnya daya dukung lingkungan.

3. Perlu dilaksanakan pemberian bantuan kepada kelompok untuk meningkatkan teknologi dengan memperhatikan daya dukung lingkungan melalui Program Pemberdayaan Ekonomi Masyarakat khusus pembudidaya udang .

4. Perlu dikembangkan dan diterapkan pengembangan kawasan pesisir Kota Tegal secara terpadu yang dinilai cukup berhasil, tetapi perlu dikembangkan. 
5. Perlu dikembangkan budidaya udang yang ramah lingkungan, melibatkan pembudidaya udang.

6. Perlu dilaksanakan penghijauan pantai dan kawasan lingkungan budidaya udang. Kegiatan ini perlu dilaksanakan secara terusmenerus.

7. Penyuluhan, pelatihan ketrampilan dan temu lapang bagi pembudidaya udang vaname untuk menerapkan teknologi ramah lingkungan dan kegiatan ini perlu dilanjutkan.

\section{KESIMPULAN}

Berdasarkan analisis matriks SWOT diperoleh peringkat alternatif strategi pengembangan sebagai berikut, peringkat I stategi SO (Strengths-Opportunities) (3,28), peringkat II strategi WO (Weaknesses-Opportunities) (2,99), peringkat III strategi ST (StrengthsThreats $)(0,69)$ dan peringkat IV strtegi WT (Weaknesses- Threats) $(2,40)$. Sedangkan berdasarkan hasil perhitungan faktor internal diperoleh total nilai sebesar 2,86 dan faktor eksternal total nilai sebesar 2,69, nilai ini menunjukan bahwa usaha budidaya udang vaname di Kawasan pesisir Kota Tegal berada dalam posisi akan mengalami pertumbuhan dan stabilitas produksi, dengan memperhatikan kebutuhan pasar dan penerapan teknologi yang ramah lingkungan, agar budidaya udang dapat berkelanjutan.

\section{DAFTAR PUSTAKA}

Adam L, Surya T.A. 2013. Kebijakan Pengembangan Perikanan Berkelanjutan di Indonesia, Jakarta. Jurnal Ekonomi \& Kebijakan Publik P3DI Bidang Ekonomi \& Kebijakan Publik, Jl. Jend. Gatot Subroto, Ged. Nusantara 1 Lantai 2, Setjen DPR RI,

Adibroto, T.A. 2002. Perencanaan Tata Ruang dalam Pengembangan Budidaya Marinkultur di Indonesia. BPPT, Jakarta.

Adiwidjaya D, I.K. Ariawan, Supito, dan E. Sutikno. 2004. Pengembangan Budidaya Udang di Indonesia: Optimalisasi Fungsi dan Peningkatan Produktivitas Tambak sebagai Komponen Hilir Budidaya Udang. Balai Besar Pengembangan Budidaya Air Payau (BBPBAP) Jepara, Jawa Tengah.

Ahmad T. 2006. Perikanan Budidaya Sebagai Langkah Maju Pemanfaatan Terkendali Sumberdaya Perairan. Jakarta: Badan Riset Kelautan dan Perikanan, Depaartemen Kelautan dan Perikanan.

Akhmad Fauzi, dan S. Anna. 2005.Pemodelan Sumber Daya Perikanan dan Kelautan: Untuk Analisis Kebijakan, Jakarta: PT Gramedia Pustaka Utama, hal. 165168.

Amri K, dan Kanna I. 2008. Budidaya Udang Vannamei Secara Intensif, Semi Intensif, dan Tradisional. PT. Gramedia Pustaka Utama. Jakarta.

Awanis AA, Prayitno SB, Herawati VE. 2017. Kajian Kesesuaian Lahan Tambak Udang Vaname Dengan 
Menggunakan Sistem Informasi Geografis Di Desa Wonorejo, Kecamatan Kaliwungu, Kendal, Jawa Tengah, Buletin Oseanografi Marina, http://ejournal.undip.ac.id/index.php/ buloma.

Bappenas, 2014. Kajian Strategi Pengelolaan Perikanan Berkelanjutan.

Boyd, C.E. 2002. Tata Laksana Budidaya Udang Bertanggung Jawab. Global Aquaculture Alliance, St. Louis MO USA.

BPS Kota Tegal, 2013-2018. Kota Tegal dalam Angka, Badan Pusat Statistik Kota Tegal.

Briggs M, Smith SF, Subasinghe R, Phillips M. 2004. "Introduction and movement of Penaeus vannamei and Penaeus stylirostris in Asia and the Pacific", RAP Publication 2004/10.

ClarkJR. 1992. Integrated Management of Coastal Zones.

FAO FisheriesTechnical Paper No. 327. United Nations-FAO, Rome, 167 pp.

Cholik F. 2003. Tujuh Pilar Pemberdaya Gema Protekan. Warta Penelitian Perikanan 5(1): 8-12.

Davis D, \& Gartside DF. (2001). Challenges for economic policy in sustainable management of marine natural resources. Ecological Economics 36(2): 223-236.

Dahuri R, R. Lacub PG, Sapta dan MJ, Sitepu. 2001. Pengelolaan Sumberdaya Wilayah Pesisir dan Lautan Secara Terpadu cetakan kedua, edisi revisi. PT Pradnya Paramita, Jakarta.

Darmawan A, Triyono, Herman, Hadi Prayitno dan Aris Supranoto. 2004. Peningkatan Produktivitas Budidaya Udang Rostris (Litopenaeus stylirostis) melalui Optimalisasi Peningkatan Air pada Sistem Tertutup, Jepara. BBPBAP Jepara.

Sagita A, Hutabarat J dan Rejeki S. 2015. Strategi Pengembangan Budidaya Tambak Udang Vaname (Litopenaeus vannamei) di kabupaten Kendal, Jawa Tengah. Journal of Aquakultur
Managemen and Technology. 4(3): 111 .

Sumiarsih. 2019. Strategi Pengembangan Budidaya Udang Vaname Skala Mini Empang Plastik (BUSMETIK) di Kecamatan Tegal Timur dan Tegal Barat, Kota Tegal [tesis]. Undip Semarang.

Hutabarat J, Pidato Pengukuhan Guru Besar : Peran IPTEK Budidaya Perairan Dalam Pengembangan dan Pemanfaatan Sumberdaya Perikanan. Fakultas Perikanan dan Ilmu Kelautan, UNDIP Semarang.

Rangkuti F. 2002. Analisis SWOT Teknik Membedah Kasus Bisnis, Reorientasi Konsep Perencanaan Strategis untuk Menghadapi Abad 21. PT. Gramedia Pustaka Utama, Jakarta. 